\title{
ANA E OS FILHOS DA VILA
}

Francisco Neto Pereira Pinto ${ }^{1}$

\author{
Bela
}

Ana

A todos seus filhos ama

Ana e Pedro viviam à beira do rio casa coberta de palha paredes de barro e piso de chão batido Uma sala cozinha e um quarto que era a glória em vida e não pediriam nada mais a Deus se vivessem sempre assim Pedro pescava nas águas mais férteis daquele Araguaia e conhecia os segredos das noites nas águas claras e correntes de quilômetros acima e abaixo daquele que era o recanto mais cálido de sua existência de cerca de vinte e cinco anos dos quais cinco foram no aconchego de Ana que era bela como Remédios subindo para o céu A esposa querida quando não acompanhava o marido em sua pesca geralmente noturna cuidava da horta que era adubada pelo húmus que se acumulava nas enormes vazantes resultantes das cheias anuais Dedicava-lhe todos os cuidados aos tomates alfaces cheiro verde abobrinha pepino jiló quiabo e repolho Cobria a rua principal com a bacia na cabeça atendendo cada cliente de porta em porta Os cabelos loiros denunciavam que era vinda de outro lugar do Goiás Compridos fazia deles um coque que pouco resistia ao vento enérgico e insistente que vinham da mata e corriam para o rio fazer arruaça nas águas que corriam apressadas depois das enormes quedas da cachoeira que roncava feroz no período de estiagem Se não saíam por interesse nas hortaliças apareciam à porta para vê-la passar faceira como somente Ana era À noite quando sozinha se punha na sacada construída por Pedro à ribanceira do rio daí abaixo um grande despenhadeiro cujo limite era a grande face da lua nas águas mornas do Araguaia que compunham o cenário romanesco e poético das leituras de Ana Sentada em sua cadeira preguiçosa ali lia poesias e romances enquanto tomava chocolate quente e esperava seu amado pescador a quem sempre avistava de longe em sua canoa grande e robusta À noite à beira do rio os ventos festejam a calmaria que despenca do céu enfeitado de estrelas sob o mundo ribeirinho A frescura que sobe do rio impõe pouco a pouco à Ana a necessidade de um agasalho mais potente e quando percebe

\footnotetext{
${ }^{1}$ Doutorando e Mestre em Ensino de Língua e Literatura pela Universidade Federal do Tocantins, câmpus de Araguaína, e professor adjunto no UNITPAC, câmpus de Araguaína. Faz formação em Psicanálise pelo IPLA, Instituto da Psicanálise Lacaniana.
} 
já está de meia nos pés enrolada com lençol Em noite avançada Pedro chega faminto mas contente com aquela que o espera com o jantar que só porque é feito pelas mãos de Ana já renova no moço toda a potência de vida Depois o mundo já não importa pois a existência que conta encerra uma soma de dois que se amam despreocupada e anonimamente sob os raios da lua boba e invejosa que entram pela janela do quarto janela que projeta uma fotografia da floresta para além rio como também um brecha de por onde os além janela podem testemunhar um pedacinho de paraíso na terra onde dois corpos se bastam indiferentes ao grande relógio da eternidade A lua não bebe vinho A lua não tem a quem amar Mas veio o tempo em que os dois desejaram o seu amor multiplicar e puseram em marcha o projeto ao qual se dedicavam com todo o interesse e pressa para acontecer Ana em período fértil era agora ainda mais solícita e atraída aos encantos de Pedro que passou a dispensar mais cuidados à alimentação e dividia com mais generosidade o tempo entre o rio e os carinhos da esposa em arroubos de amores para que a criança fosse concebida no mais árduo calor do amor

Mas a biologia dá de ombros ao amor

Segue seu próprio destino pega outros caminhos

Para o desespero de Pedro e Ana o horror

Acudiram ao casal as mais experientes do vilarejo uma garrafada uma receita um conselho Ana foi se tornando toda tristeza Pedro vagava pelas águas do Araguaia às vezes sem rumo meditativo Os raios do sol atingiam as águas como flechas à procura do fundo do rio tal como os olhos do moço que esquadrinhavam as profundezes em busca de sentido Sua dor não era tanto pelo filho que não vinha mas pela mulher que se ia veloz derramando em correntezas como as corredeiras que se formam a partir da cachoeira Iam-se também as palavras de consolo e os abraços já pareciam não ter o calor costumeiro já não eram para Ana um aconchego Sentia-se aos poucos como os redemoinhos e passou a gostar de se perder pelos caminhos das águas tão conhecidos de anos de pesca Também não tinha coragem de ir ao médico e descobrir onde estava a pedra no caminho dos seus sonhos de amor com Ana $\mathrm{Na}$ dúvida compartilhavam o fardo da culpa por não poderem dar um ao outro o filho tão sonhado Compartiam também olhares vagos e fugidios apressados sempre por alguma outra coisa um esconderijo qualquer que não a morada que se 
prometeram um ao outro Perceberam então que não sentiam a mesma dor e que a ferida é mesmo sempre medida única Ana às vezes sentava na varanda e olhava as águas que passavam tão desinteressadas de nada querendo saber do que se revolvia em suas vidas Sentia inveja delas tão impávidas sempre indo aonde deviam ir fazendo frente a qualquer empecilho Quis muito ser aquelas águas e se despossuir daquele corpo que agora tanto a fazia sofrer Depois enraivava de si mesma e das águas e sentia crescer no ventre um desejo leviano mas doce e macio como do chocolate quente cremoso de se lançar ao convite daquele solícito despenhadeiro e se fazer andorinha e voar ao encontro dos mistérios insondáveis do fundo do rio Descansaria docemente na negra escuridão e jamais para sempre nunca mais sentiria tão aguda agonia de não ser mãe

\section{A vida como o rio corre}

A vida como o rio de turbulência intensa e imensa

Viver assim como o rio pede urgência

Ana retornou à horta em longas horas de adubos cuidados e desabafos As plantas se tornaram confidentes e cúmplices de suas dores e lágrimas e viçavam em clara demonstração de que a compreendiam e eram solidárias à tragédia que havia despencado do alto das montanhas em sua alma delicada e suave que agora começava a brotar novamente os tons da poesia sonora e sonhadora de Cecília Meireles que Ana lia cantante com sua voz suave para toda a horta verdejante que dançava os embalos poéticos sob os sopros úmidos e vigorosos dos ventos que vinham do rio vadiar para alegrar o dia daquela que já não se sentia tão solitária como andorinha perdida A poesia o rio os ventos a horta a terra e os céus ali a entendiam Sentia-se protegida dos olhares pontiagudos de condescendência e dos edificantes conselhos que pesam toneladas e que faz morrer até a última centelha de vida Em casa sobre o peito de Pedro descansa o rosto e ouve sob a noite silenciosa o canto apaixonado daquele coração que lhe transborda de amor e às vezes derrama uma cálida lágrima e outras apenas dorme Vez por outra tomam chocolate quente na varanda sob um céu tão imenso quanto seus desejos de um fruto seus que lhes tornaria a vida ainda mais completa Assim são os sonhos um gel de babosa sobre a ferida do viver nesta terra do tudo e do nada Falam dos sonhos da pedra no caminho da dor e do amor Choram Abraçam com apertos doces e fortes Calam-se Espiam a grande noite que se abate 


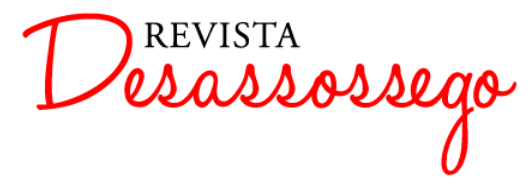

DESASSOSSEGO 19 | JUN/2018 | ISSN 2175-3180

DOI: http://dx.doi.org/10.11606/issn.2175-3180.v10i19p203-206

sobre o mundo sobre a vila sobre sua varanda e sobre suas cabeças Em frente à volumosa água que corre apressada sob o suave brilho da lua que vigia desde o céu

\section{Ainda chora pelos idos e perdidos}

Mas da vila ganhou

Filhas e filhos

Ana foi à escola da vila propor aulas de poesia Lia de graça seus próprios livros e recebia como supremo pagamento todos os sorrisos rompantes e abraços mornos dos filhos que nunca teria Lia, enternecia e chamava a todos de seus queridos filhinhos Depois passou a oferecer para a cozinha escolar no dia de suas aulas de leitura todos os produtos de sua horta cujo preço é que comecem tudo com muito gosto e voracidade pois era essa toda recompensa de que precisava $\mathrm{E}$ assim cultivava Ana sua horta e seus filhos com muita poesia e sua própria vida Pedro deitava os olhos sobre a esposa e brilhavam como as gotas das águas claras do Araguaia que brincam sob o sol quando descambam na cachoeira Iam como as várzeas germinando vida depois de longos meses de estiagem Sentia que era tomado de um amor urgente que reacendia em Ana o desejo de tê-lo como seu amante pescador que existe somente para si no quarto banhado pela luz apaixonada da lua que entra pela janela aberta para o rio que ronca logo ali na cachoeira Longe toca uma música é bonita E nada mais importa

Do céu

Um pedacinho de amor

Téo 